\title{
THE APPROACH OF ONE HEALTH CONCEPT IN ADDRESSING THE SPREAD OF ZOONOTIC DISEASES IN INDONESIA
}

\author{
Faika Rachmawati ${ }^{1}$, Khariri ${ }^{2}$ \\ ${ }^{1}$ Center for Health Research dan Development of Public Health Effort \\ ${ }^{2}$ Center for Research and Development of Biomedical and Basic Health Technology \\ Corresponding author: arie.tegale@gmail.com
}

\begin{abstract}
Most infectious diseases in the world are zoonotic diseases. Zoonotic diseases are now a public health problem that is taking the world's attention because it can cause a pandemic. Zoonotic pandemic diseases can have a very large impact on people's social and economic life. This article is a literature review of the approach of one health concept in addressing the spread of zoonotic diseases in Indonesia. Data collection is carried out through research libraries in the form of scientific journals, books, articles in mass media, and online media. Improving the world of livestock in Indonesia has an impact on humans and the environment. This can increase the risk of transmitting various infectious diseases from animals to humans. The spread of disease occurs quickly and can reach areas not limited by cities, islands, even continents. Zoonotic diseases are closely related to animals and humans, so the planning and control efforts undertaken must involve many people in charge, especially in the animal, human and environmental health sectors. Starting from the joint vigilance, the concept of One Health was born. One health approach needs to involve cross-sectoral and cross-disciplinary by integrating professional concepts in animal health and human health. The concept of one health comprehensively looks at the components related to the process of emergence and spread of zoonotic diseases so that the picture of the disease is more complete and makes it easier to overcome.
\end{abstract}

Keywords: animal health, cross sector, one health, public health, zoonotic diseases

\section{Introduction}

Animal-borne diseases can occur because of an imbalance between the host, agent and environment (1)Environmental damage due to land use change, waste (household and industrial) and natural disasters is a susceptibility factor for the emergence of diseases, one of which is zoonoses (2). Zoonoses are diseases that are transmitted naturally between animals and humans. Livestock in Indonesia are vulnerable to various zoonoses, so zoonoses are a new threat to human health (3).

The world is experiencing an increasing threat of new infectious diseases or known as emerging infectious diseases (EID) and 70 percent are vector-borne and zoonotic diseases (4). This threat greatly affects the life, safety, welfare and economy of the community (5). The outbreak from EID has multi-aspect impacts and many fatalities due to the system's unpreparedness to synergize. The threat of zoonotic diseases is what triggers the concept of One Health (6).

One Health requires us to realize that an occurrence of disease in one place means that the world is sick. In the concept of One world health is one body. The complexity, causes, triggers, scope involved and impact of disease outbreaks make zoonotic control cannot be done by just one expertise. Veterinarians only focus on the source of the disease, which is certainly not sufficient to solve problems in humans and the environment (2).

To control zoonotic problems, local and regional cooperation is required. Several zoonoses that have become epidemic can occur and have a profound effect on local
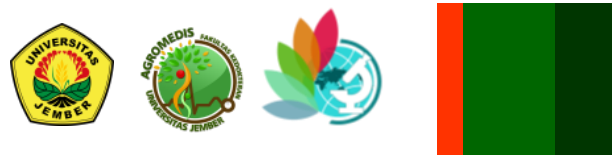
communities. This zoonotic epidemic is spreading both within and outside the country of origin, thus potentially destabilizing a country (7). Integrated handling is needed by involving cross-sectoral and expertise. In the concept of one health, collaboration between national and international organizations is needed so that it can reduce the occurrence of zoonoses (8). This article is a review and descriptive analysis of publications in scientific journals, books, articles in mass media and online media about the one-health concept approach in dealing with the spread of zoonotic diseases in Indonesia.

\section{Methods}

This article is a search result of news reports, reports, and literature with a scoping review design. The Scoping review design is a one-health concept approach in dealing with the spread of zoonotic diseases that has been carried out by multi-sectors and multidisciplines in Indonesia. Sources of information come from articles in scientific journals, books, articles in mass media and online media. The search is done by entering keywords according to the topic of study and the literature search strategy combining keywords from various categories. Data analysis was carried out descriptively.

\section{Results}

\section{Human, Animal and Their Products Interaction}

The interaction between environmental components with one another cannot be separated and will continue to change according to human needs. Animal husbandry is an effort to meet the increasing needs of human life, especially poultry and beef cattle production. The collection of animals in large numbers has an impact on the surrounding environment. The increase in livestock business activities is one of the causes of the spread of animal diseases to humans and / or to other animals or zoonoses. About three- quarters of infectious diseases in humans are of animal origin (9).

Zoonoses can be distinguished, among others, based on transmission, the main reservoir, the origin of the animal that spreads them, and the causative agent. Based on the causative agent, zoonoses are differentiated into zoonoses caused by bacteria, viruses, parasites, or those caused by fungi (10). As many as $75 \%$ of new diseases (emerging diseases) in humans occur due to the transfer of animal pathogens to humans or are zoonotic (11).

According to Brown, of the 1415 pathogenic microorganisms in humans, $61.6 \%$ came from animals. A number of zoonoses that are strategic infectious animal diseases in Indonesia, namely rabies, anthrax, avian influenza, salmonellosis and brucellosis. Other important zoonoses that need more attention include schistosomiasis, cysticercosis or taeniasis, tuberculosis, leptospirosis, toxoplasmosis, Japanese encephalitis, streptococosis or staphylococosis, and clostridium (tetanus). Zoonoses related to food safety (food borne disease) in Indonesia are camphylobacteriosis, salmonellosis, shigella, yersinia, verocyto toxigenic Escherichia coli (VTEC), and listeriosis. The exotic zoonotic diseases for Indonesia are bovine spongiform encephalopathy (BSE), Nipah/Hendra virus, ebola, and rift valley fever (RVF) (12). Rabies is a zoonosis that has been recognized since early history and other diseases such as BSE (Bovine Spongiform Encephalopathy) are recognized as newly emerging (13).

Emerging zoonoses are zoonoses that are newly recognized or have occurred previously but show an increase in the incidence or spread within an area, host or vector. Some of the emerging zoonoses that have occurred in the last 20 years are Ebola virus, bovine spongiform encephalopathy (BSE), Nipah virus, rift valley fever (RVF), alveolar echinococcosis, severe acute respiratory syndrome (SARS), and
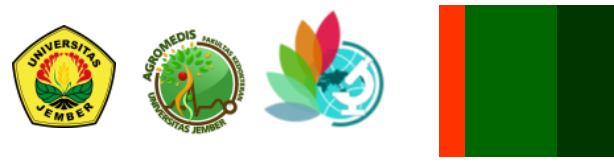
monkeypox (11). Meanwhile, several emerging zoonoses that are of concern are highly pathogenic avian influenza (HPAI), hantavirus pulmonary syndrome, West Nile fever (in the United States), lyme disease, haemolytic uraemic syndrome (Escherichia coli serotype O157: H7), and Hendra virus (14). Diseases that are included in reemerging zoonoses are rabies and infection with the Lyssa virus, rift valley fever (RVF), Marburg virus, bovine tuberculosis, brucella $\mathrm{sp}$ in wildlife, tularemia, plaque, and leptospirosis (12).

\section{Impact of Zoonoses}

Zoonoses cause mild to severe effects and can even be fatal. The Ministry of Agriculture has determined 15 priority zoonoses to be controlled and overcome, including Avian Influenza, Rabies, Anthrax, Brucellosis, Leptospirosis, Japanese B. Encephalitis, Bovine Tubercullosis, Salmonellosis, Schistosomiosis, Q Fever, Campylobacteriosis, Trichinellosis, Paratubercullosis, and Toxoplasmosis or Taniasis. Zoonoses can be transmitted from animals to humans in several ways, namely direct contact with infected animals and indirect contact through vectors or consuming food originating from sick livestock, or through aerosols when a person is in a polluted environment (12).

Based on the infectious animal, zoonoses are divided into zoonoses originating from wildlife, zoonoses from animals that are not kept but are around the house, such as rats that can transmit leptospirosis, and zoonoses from animals kept by humans. Diseases suffered by livestock during maintenance can be transmitted to humans through the consumption of foodstuffs of the animal origin. The high prevalence of zoonoses has a big effect both economically and psychologically, especially the boycott of the trade in animal products between countries and psychologically people are reluctant to consume meat and its processed products. Most cases of foodborne disease that are reported are generally related to food of animal origin or zoonotic nature. In Indonesia, cases of poisoning are reported to be increasing, and poisoning through food is a commonly reported case (10).

Infections and foodborne poisoning due to exposure to foods of animal origin create serious problems in human health. Hygiene and food safety issues that occur along the food chain result in zoonoses that are transmitted through food (15). Crossborder animal diseases, international livestock trade, interactions of wild animals with animals and humans as well as new feeding behaviors for animals and humans contribute to the occurrence of emerging and reemerging disease zoonotic diseases. Animal health, hygiene and food safety of animal origin are growing and difficult challenges that are clearly included in the new global health agenda for animal production and food supply (16).

\section{Livestock Production}

The transmission of disease from animals to humans is not limited to human relations with domesticated animals, but also with domestic animals and wild animals. The facts show that wild animals such as wolves and bats are a direct or indirect source of rabies for humans and domestic animals. In cold blooded vertebrates such as snakes and turtles, Salmonella and Brucella abortus have also been found. Erysipelas and Clostridium were found in fish (17).

\section{Economy}

The economic impact can include loss of workforce due to illness, a decrease in the number of tourists to the area where the outbreak occurs, a decrease in the production of livestock and livestock products, the culling of sick cattle and sick suspects, as well as restrictions and decreases in international trade. A person infected with zoonoses will reduce work power. This situation does not
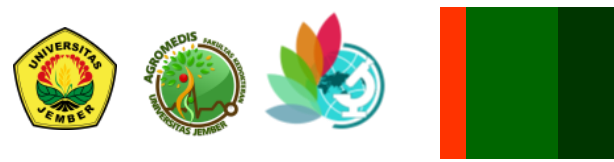
only occur in rural areas, but also in urban areas, for example for workers in meat and other animal product processing factories, workers in slaughterhouses, sellers of meat and animal products, food processors in food stalls and restaurants. Health problems for them will also reduce the quality of human resources so that it affects the socio-economic sector of the family and society as well as state income (1).

\section{Social Activities (Public Health and Individual Health)}

The number of victims who die from rabies reaches more than 100 people every year. Indonesia even ranks top in the world in terms of the number of deaths in humans due to bird flu. From the economic simulations based on the 2006 database, a bird flu pandemic will result in direct losses of up to 14-48 trillion (3). Management of zoonoses requires costs for treatment. Another loss can be in the form of decreased work productivity due to illness suffered by workers or breeders (18).

\section{Defense}

In today's high-tech era, the issue of a country's resilience which previously focused on the advancement of high-warhead (nuclear) weapons is now beginning to shift to biological weapons that use biological agents (microorganisms) as a source/cause of deadly disease which is often known as bioterrorism. A threat that is far more dangerous than just war using nuclear weapons (conventional). This is because the ability to kill them is broader than any form of firearm or nuclear weapons. The effects of biological weapons on human mortality and environmental contamination by pathogenic agents can last a long time. This is what the world is afraid of. In almost all countries in the world the threat of biological weapons (bioterrorism) is the main topic of discussion in the framework of a country's resilience (3).

\section{Epidemic}

Currently, 24 provinces in Indonesia are rabies endemic areas and nine provinces are declared rabies-free areas. Of the 9 provinces, five provinces are historically independent, namely Bangka Belitung, Riau Islands, NTB, West Papua and Papua. Four other provinces were declared free of rabies, namely Central Java, DI Yogyakarta, East Java and DKI Jakarta. (19). Anthrax is arguably the oldest zoonosis ever reported. Anthrax is a zoonosis that can be transmitted through food. Areas that are endemic to anthrax in Indonesia are 14 provinces, namely Sumatra, Jambi, West Java, Central Java, DKI Jakarta, South Sulawesi, Southeast Sulawesi, Central Sulawesi, West Nusa Tenggara, East Nusa Tenggara, Yogyakarta, East Java, West Sulawesi and Gorontalo (20).

\section{Discussion}

\section{One Health Concept}

One health is a collaborative, multidisciplinary and multisectoral approach that can address urgent, ongoing, or potential health threats between humans and animals at subnational, national, global and regional levels. This concept is a reflection of the high proportion of zoonoses among emerging diseases in the last 30 years (21).

One health is an important global activity based on the concept that human, animal, and environmental or ecosystem health is interdependent or interdependent. The one health concept is used to strengthen prevention and enable faster detection and response to zoonotic threats. The One health concept is a worldwide strategy for expanding interdisciplinary collaboration and communication in all aspects of health care for humans, animals and the environment. The one health concept focuses on controlling various infectious diseases that are transmitted between animals, humans and the environment $(22,23)$. Most infectious diseases are caused by microbes and are zoonotic in nature. Environmental changes will continue
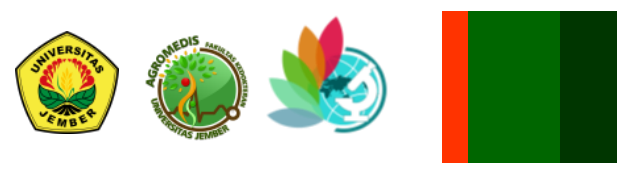
to create favorable conditions for the development of new zoonoses (24).

\section{Scope of One health}

One health is increasingly recognized at the global, regional and country levels. Not only for the prevention and control of zoonoses but also in response to antimicrobial resistance (AMR), food safety and climate change issues (25). The coverage of one health is very broad and below it contains various disciplines that can contribute (26).

One health aims to reduce major risks and impacts on animal and human ecosystems. It is an approach to dealing with complex challenges at the intersection of animals, humans and environmental health. Integrated coordination in various sectors and in a professional manner to improve health and well-being in the long term. This concept emphasizes a multi-sectoral approach and cross-sector collaboration and collaboration (26). The multi-sectoral and interdisciplinary approach encourages collaborative efforts of various sectors and disciplines working locally, nationally and globally to tackle common health threats and achieve the best health for humans, animals and the environment (27).

The animal health sector ensures a production system from the aspect of animal health and reduces risk factors. Public health minimizes the risks associated with zoonotic diseases. The field of environmental health is closely related to environmental science and public health, as environmental health pays attention to environmental factors that affect human health (26). Environmental health, as used by the WHO Regional Office for Europe, includes both the direct pathological effects of chemical agents, radiation, and some biological agents, as well as effects on the health and safety of the environment at large physical, psychological, social and cultural levels, including housing, development. urban, land use and transportation
The emergence of zoonotic diseases that are feared by all countries is actually controllable, such as the process of providing safe foodstuffs. National policies on integrated zoonotic control strategies which include prevention, coordination and synergy of resources, integrated surveillance or observation, protection of free areas, protection of communities, strengthening resource capacity, research and development, and community empowerment. This regulation can actually be used as a control tool for the occurrence of zoonotic diseases in Indonesia (28).

The concept of one health is rarely applied at the community level. It cannot be denied that community involvement is very important in reducing the risk of zoonoses (7). The birth of the One health concept requires us to realize that life in our world is one, in order to achieve global health. Good coordination by involving the community and science, especially stakeholders, can be the best solution in managing zoonoses (29).

The willingness of every citizen to work together is the key in managing the successful management of zoonotic diseases in the community. Community participation is expected to help stakeholders so that they can influence individual behavior in applying the One Health concept (30). It is hoped that cross-sectoral roles will not stop in a concept, but also need activities that can be directly carried out in a sustainable and integrated manner and are actively reported or published (31). Veterinary practitioners are part of the One Health concept and have played a role in preventing and controlling zoonoses (2).

The implementation of One health in Indonesia itself has progressed and continues to be developed to achieve global health. Training, seminars, and even workshops need to be carried out together as a form of cooperation between stakeholders in the health sector and across other sectors. Increasing knowledge is very necessary, especially in the field of epidemiology, as
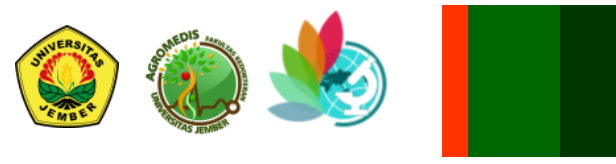
well as the implementation of zoonotic studies that run simultaneously on people, domestic animals and wildlife (32).

The One Health strategy is focused on reducing risk due to zoonoses by improving disease intelligence, integrated and systematic cross-species surveillance, collaborative research related to animals, humans and the environment in order to detect early possible diseases and activate an emergency response preparedness system (33). The application of the concept of One health in the field needs to eliminate the imbalance between structural, bureaucratic, political and cultural at each layer Cross-sector cooperation is needed to ensure better preparedness and contingency planning. A more efficient and effective surveillance system, sharing costs between sectors according to the benefits of control, increasing the distribution of logistics and costs for service provision are the right steps in dealing with zoonoses (34). Cross-sector cooperation needs to be a major concern to determine the determinants and consequences of zoonoses, as well as appropriate interventions to reduce the damage that will occur due to the outbreak of these zoonotic diseases (35).

Zoonoses can still be controlled, prevented and possibly eliminated through a one health approach using a combination of effective and feasible interventions. This includes preventive chemotherapy, medication, vaccination and management of animal reservoirs, safe food preparation and handling, provision of clean water, good hygiene and sanitation, and through strong inter-sectoral partnerships and partnerships (36).

\section{Conclusions}

Zoonotic infections are closely related to animals, humans and the environment, so that planning and control efforts must involve many responsible people, especially in the animal, human and environmental health sectors. The concept of One health was born as a form of mutual vigilance. The One health me concept involves cross-sectoral and crossdisciplinary by integrating professional concepts in animal health and human health. The One health concept comprehensively looks at the components related to the process of emergence and spread of zoonoses so that the disease picture is more complete and makes it easier to treat.

\section{References}

[1] Yudhastuti R. Penyakit Bersumber Binatang dan Pengendaliannya. Surabaya: Pustaka Melati; 2012. 110 p.

[2] Swacita IBN. One Health. Denpasar: Fakultas Kedokteran Hewan Universitas Udayana; 2017.

[3] Khairiyah. Zoonosis dan Upaya Pencegahannya (Kasus Sumatera Utara). J Litbang Pertan. 2011;30(3):117-24.

[4] BAPPENAS. Fungsi Kesehatan Masyarakat dan Kesehatan; Kajian Sektor Kesehatan. 2019.

[5] UCAR Center for Science Education. Climate Change and Vector-Borne Disease. 2014.

[6] Kementerian Koordinator Pembangunan Manusia dan Kebudayaan. Implementasi One Health di Indonesia. 2016.

[7] Hassan OA, Affognon H, Rocklöv J, Mburu P, Sang R, Ahlm C, et al. The One Health approach to identify knowledge, attitudes and practices that affect community involvement in the control of Rift Valley fever outbreaks. PLoS Negl Trop Dis. 2017;11(2):1-12.

[8] Hassan OA, Ahlm C, Evander M. A need for One Health approach - lessons learned from outbreaks of Rift Valley fever in Saudi Arabia and Sudan. Infect Ecol Epidemiol. 2014;4(1):1-8.

[9] Cleaveland S, Laurenson MK, Taylor LH. Diseases of humans and their domestic mammals: Pathogen characteristics, host range and the risk of emergence. Philos Trans R Soc B Biol Sci. 2001;356(1411):991-9.

[10] Murdiati T, Sendow I. Zoonosis yang Ditularkan Melalui Pangan. Wartazoa. 
2006;16(30):14-20.

[11] Brown C. Emerging zoonosis and pathogens of public health significance-an overview. Rev sci tech Off int Epiz. 2004;23(2):435-42.

[12] Putri TS. Kebijakan Penanggulangan Penyakit Zoonosis Berdasarkan Prioritas Departemen Pertanian. 2014.

[13] Fosse J, Seegers H, Magras C. Foodborne zoonoses due to meat: A quantitative approach for a comparative risk assessment applied to pig slaughtering in Europe. Vet Res. 2008;39(1):1-16.

[14] Morse SS. Factors and determinants of disease emergence. OIE Rev Sci Tech. 2004;23(2):443-51.

[15] Newell DG, Koopmans M, Verhoef L, Duizer E, Aidara-Kane A, Sprong H, et al. Food-borne diseases - The challenges of 20years ago still persist while new ones continue to emerge. Int J Food Microbiol. 2010;139(SUPPL. 1).

[16] Gebreyes WA, Dupouy-Camet J, Newport MJ, Oliveira CJB, Schlesinger LS, Saif YM, et al. The Global One Health Paradigm: Challenges and Opportunities for Tackling Infectious Diseases at the Human, Animal, and Environment Interface in Low-Resource Settings. PLoS Negl Trop Dis. 2014;8(11).

[17] Suradi K. Pengendalian Zoonosis melalui Mangement dan penanganan Bahan Pangan Hasil Ternak. Bandung: Universitas Padjadjaran; 2004.

[18] Basri C, Sumiarto B. Taksiran Kerugian Ekonomi Penyakit Kluron Menular (Brucellosis) pada Populasi Ternak di Indonesia (THE ESTIMATION OF ECONOMIC LOSSES CAUSED BY BRUCELLOSIS IN LIVESTOCK POPULATION IN INDONESIA). J Vet. 2018;18(4):547.

[19] Kementerian Kesehatan. Infodatin Rabies 2017. 2017;

[20] Kementerian Pertanian. Pedoman Pengendalian Dan Pembatasan Penyakit Hewan Menular (PHN): Seri Penyakit Antraks. 2016.

[21] KE, Patel NG, Levy MA, Storeygard A, Balk D, Gittleman JL, et al. Global trends in emerging infectious diseases. Nature.
2008;451(7181):990-3.

[22] Graham JP, Leibler JH, Price LB, Otte JM, Pfeiffer DU, Tiensin T, et al. The animalhuman interface and infectious disease in industrial food animal production: Rethinking biosecurity and biocontainment. Public Health Rep. 2008;123(3):282-99.

[23] Coker R, Rushton J, Mounier-Jack S, Karimuribo E, Lutumba P, Kambarage D, et al. Towards a conceptual framework to support one-health research for policy on emerging zoonoses. Lancet Infect Dis. 2011;11(4):326-31.

[24] Kahn LH. Causa Acidentes Laborais 2. 2006;12(4).

[25] Gongal G, Ofrin RH, de Balogh K, Oh Y, Kugita H, Dukpa K. Operationalization of One Health and tripartite collaboration in the Asia-Pacific region. WHO South-East Asia J public Heal. 2020;9(1):21-5.

[26] Southeast Asia One Health Network. Pedoman Aplikasi Hard Skill One Health. Depok: Indohun National Coordinating Office; 2014.

[27] Gryphon Scientific. Pelatihan: Research Translation untuk Mengatasi Tantangan One Health: Menggunakan Riset untuk Memperkuat Kemampuan Pencegahan dan Kontrol Penyakit Zoonosis di Indonesia. 2019.

[28] Presidential Regulation. Anthrax Control. 2011.

[29] Rüegg SR, McMahon BJ, Häsler B, Esposito R, Nielsen LR, Speranza CI, et al. A blueprint to evaluate one health. Front Public Heal. 2017;5(FEB):1-5.

[30] Binot A, Duboz R, Promburom P, Phimpraphai W, Cappelle J, Lajaunie C, et al. A framework to promote collective action within the One Health community of practice: Using participatory modelling to enable interdisciplinary, cross-sectoral and multi-level integration. One Heal. 2015;1(1):44-8.

[31] Cars O, Xiao Y, Stålsby Lundborg C, Nilsson LE, Shen J, Sun Q, et al. Building bridges to operationalise one health - A Sino-Swedish collaboration to tackle antibiotic resistance. One Heal. 2016;2:139-43.

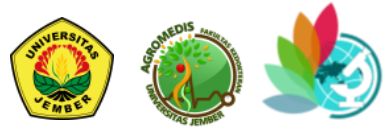


[32] Center For Indonesian Veterinary Analitycal Studies. Rumusan Seminar Nasional "Konsep One Health dalam Rangka Penanggulangan Penyakit Zoonosis." 2008.

[33] Naipospos TSP. Strategi Mengurangi Risiko Penyakit Dengan Fokus Pada Interaksi Manusia, Hewan Dan Lingkungan - Kontribusi Bagi Konsep One World One Health. CIVAS. 2020.

[34] Braks M, Medlock JM, Hubalek Z, Hjertqvist M, Perrin Y, Lancelot R, et al. Vector-borne disease intelligence: Strategies to deal with disease burden and threats. Front Public Heal. 2014;2(DEC).

[35] Mazet JAK, Clifford DL, Coppolillo PB, Deolalikar AB, Erickson JD, Kazwala RR. A "One health" approach to address emerging zoonoses: The HALI project in Tanzania. PLoS Med. 2009;6(12).

[36] World Organisation for Animal Health. Meeting to accelerate prevention and control of neglected foodborne parasitic zoonoses in selected Asian countries. 2018. 